\title{
Residents' perspective on the quality of postgraduate training programs in Pakistan - the good, the bad and the ugly
}

\author{
Laima Alam, Jawad Khan², Mafaza Alam³, \\ Varqa Faraid ${ }^{4}$, Fahad Ajmal ${ }^{5}$, Laila Bahadur 6
}

\begin{abstract}
Objectives: To assess the satisfaction of trainees towards different attributes of their training programs. Methods: This cross-sectional survey was carried out by enrolling trainee doctors currently working in Medical, Surgical, Dental and Allied specialties of the country by sending a validated and piloted questionnaire through email. Data collection was done from $1^{\text {st }}$ to $31^{\text {st }}$ January 2021 after taking ethical approval from the concerned authorities. Data was analysed using SPSS v. 19.0.

Results: A total of 516 completed responses were received from 15 major cities of the country. The overall perceived satisfaction towards clinical skills $(42 \%)$, teaching skills $(31.4 \%)$, personal growth and development $(23.6 \%)$, research $(21 \%)$ and supervisor's role $(44.2 \%)$ were considerably low with the most common causes for non-satisfaction being poor work-life balance (59\%), financial instability (54.5\%), poor research facilities (53\%), poor career guidance (44\%) and poor skill development $(42.4 \%)$ in descending order. Senior years of residency, government and private set-ups, less than four and greater than 13 residents on average with less than three supervisors per department, excessive duty hours and financial instability in-lieu of not doing locums were statistically related to poor satisfaction across majority of the facets of residency as well the overall satisfaction towards training programs.

Conclusion: There is a tremendous scope for improvement in the recognized and partially acknowledged attributes of our training programs. Yearly feedback surveys involving residents is essential for enlightening the authorities and mitigating the trainees' grievances.
\end{abstract}

KEYWORDS: Clinical skills, Medical education, Postgraduate training, Quality of training Survey.

How to cite this:

doi: https://doi.org/10.12669/pjms.37.7.4297

Alam L, Khan J, Alam M, Faraid V, Ajmal F, Bahadur L. Residents' perspective on the quality of postgraduate training programs in Pakistan - the good, the bad and the ugly. Pak J Med Sci. 2021;37(7):1819-1825. doi: https://doi.org/10.12669/pjms.37.7.4297

This is an Open Access article distributed under the terms of the Creative Commons Attribution License (http://creativecommons.org/licenses/by/3.0), which permits unrestricted use, distribution, and reproduction in any medium, provided the original work is properly cited.

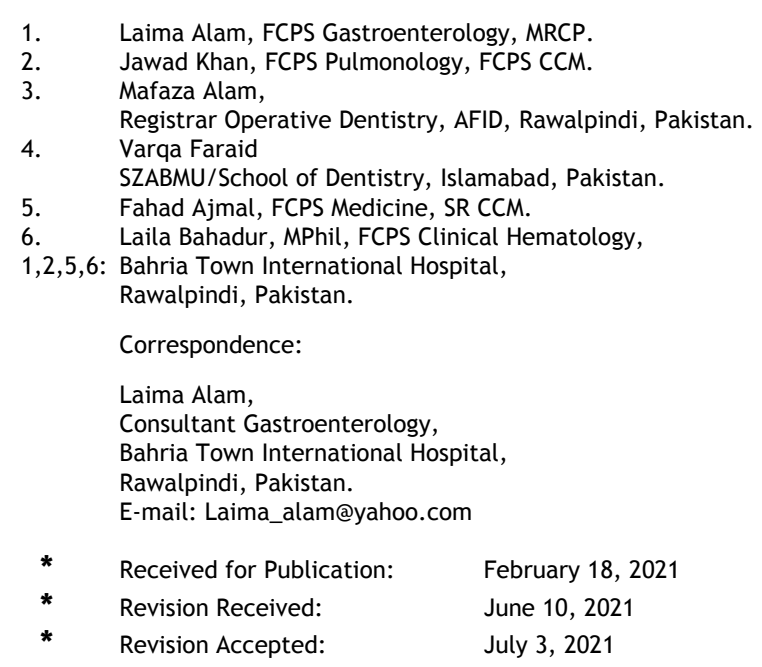

Pak J Med Sci November - December 2021

\section{INTRODUCTION}

The objective of medical residency programs has moved from the bare minimal standard attainment to an elaborate system of continuous improvement with frequent appraisals and evaluations for validation. ${ }^{1}$ Accreditation of a highly robust residency program involves work environment, academics and its balance with service, evaluations, mentorship and the qualities of the supervisors. ${ }^{2}$ Frequent scientific evaluation of training programs has long been advocated to ensure safe and productive environment for the residents that in turn affects performance and adequate patient care. ${ }^{3}$ 
Every medical education program, be it undergraduate or post-graduate, requires a system of continuous analysis, policy making and reassessing the improvements brought about by the implemented strategies. ${ }^{4}$ Unfortunately, there is a serious dearth of such quintessential research in our country, leading to uneven quality of training with rising stress, maladaptive coping strategies and feeling of abandonment in majority of the trainee doctors. An extensive literature review showed that only a few studies were conducted to identify unrecognized deficiencies of our training programs and that too were either geographically limited to a single centre, city or a province or a single specialty, ${ }^{3,5-7}$ leading to results that could not be generalized.

This nation-wide cross-sectional survey was designed to measure the level of satisfaction of our residents working in varied set-ups towards various facets of residency that were not previously studied locally. The relation of multiple demographic variables with satisfaction scores was also studied in detail.

\section{METHODS}

This cross-sectional survey was carried out by enrolling trainee doctors working in different cities of Pakistan through convenience sampling after acquiring ethical approval from the concerned department (A/01/21/13, dated January 1, 2021). The survey was completed in one month i.e.; from $1^{\text {st }}$ January 2021 to $31^{\text {st }}$ January 2021 by enrolling trainee doctors currently working in Medical, Surgical, Dental and Allied specialties of the country. Trainees from basic medical sciences, non-trainee doctors and those with less than six months experience were all excluded.

The questionnaire was developed by LA, MA and JK after a thorough literature review ${ }^{5-8}$ and was reviewed by two medical education experts for content validity. The survey was piloted among 10 post-graduate residents before putting it to test. The questionnaire encompassed perceived satisfaction towards six main facets of residency programs including clinical skills, teaching, personal growth and development, research, supervisor's role and environment of the training institute. ${ }^{9}$ The perceived quality was scored using Likert five-point scale ranging from strongly agree (1) to strongly disagree (5). Questions regarding each domain of the residency programs were followed by a Yes/No question in order to enable the participants to select their over-all satisfaction regarding that domain.

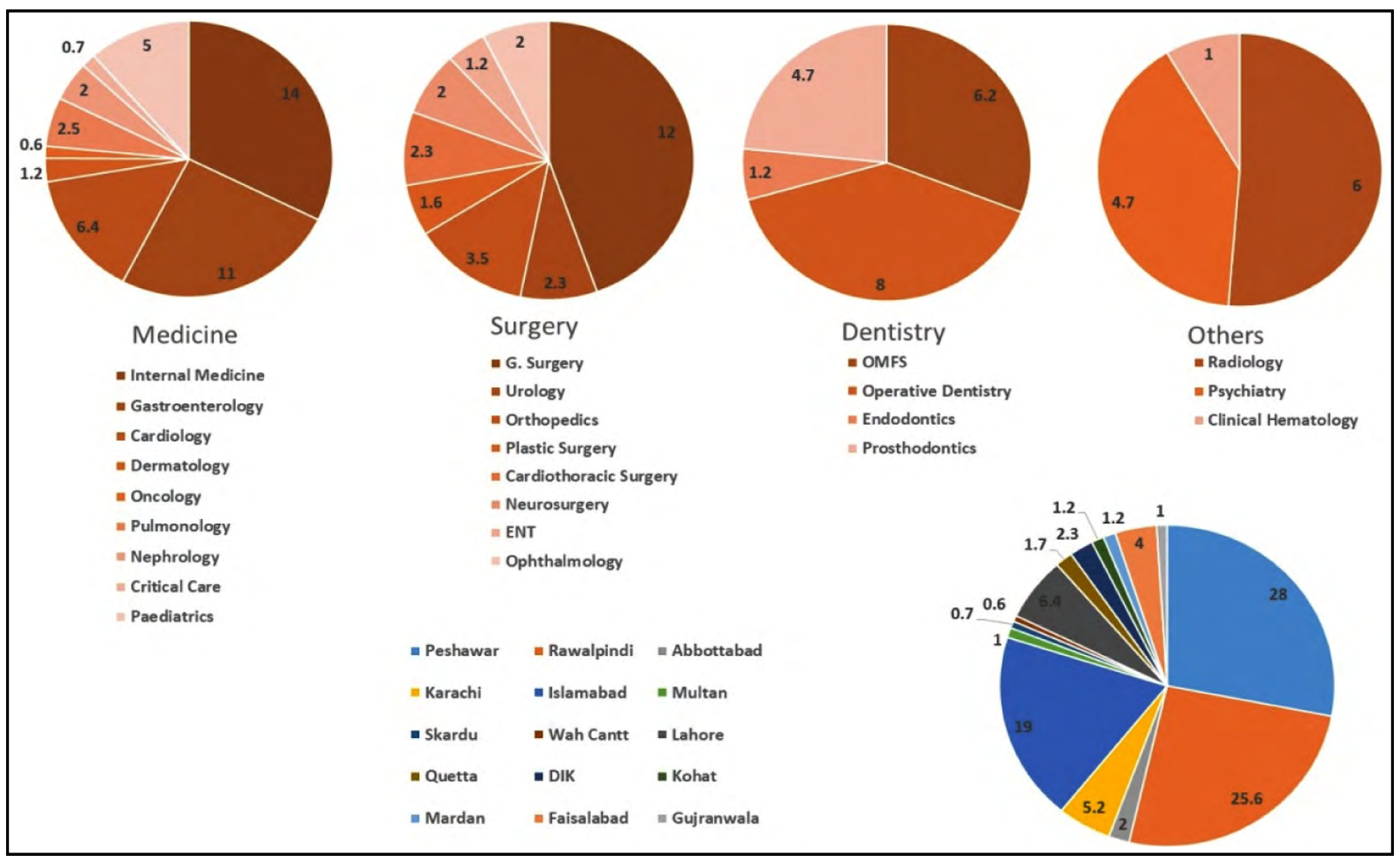

Fig.1: Distribution of different specialties and cities of residency. 
The sample size was calculated with margin of error set at $4.5 \%$, confidence level at $95 \%$ and an anticipated frequency (response distribution) of $50 \%$ using OpenEpi sample size calculator. The questionnaire was sent through email, a reminder was given to the participants after one week of no response and the candidates were dropped who failed to respond after another seven days. ${ }^{10}$

Statistical Analysis: To measure the internal consistency of the instrument, Cronbach's alpha was calculated which produced a value of 0.95 . Qualitative data was expressed as frequencies and percentages. Relation of non-satisfaction with socio-demographic variables was seen using multinomial logistic regression. A value of $<0.05$ was considered statistically significant. All analysis was done using SPSS V.19.

\section{RESULTS}

A total of 516 completed responses were received (from 15 major cities of the country representing all the provinces as shown in Fig.1) out of 960 emails sent, making a response rate of $53.7 \%$. Male participants $(65.7 \%)$ with a median age of $24-30$ years $(63 \%)$ getting trained at government $(47 \%)$ followed by army set-up (34.4\%) showed maximum participation. An average of 26-30 working days $(51.7 \%)$ with $4-6$ on-calls $(28 \%)$, 1-3 long-days $(22.7 \%)$ and 1-2 weekends-on-call $(70 \%)$ was the rota per month for majority of the trainees (Table-I).

The scores of perceived satisfaction using a fivepoint scale for different facets of training is shown in Table-II. The overall perceived satisfaction towards clinical skills (42\%), teaching skills (31.4\%), personal growth and development (23.6\%), research $(21 \%)$ and supervisor's role $(44.2 \%)$ were considerably low with the most common causes for non-satisfaction being poor work-life balance (59\%), financial instability $(54.5 \%)$, poor research facilities $(53 \%)$, poor career guidance $(44 \%)$ and poor skill development (42.4\%) in descending order (Fig.2).

Table-I: Demographics of the participants enrolled

\begin{tabular}{|c|c|c|}
\hline Variables & Frequency & Percentage \\
\hline Gender (M/F) & $339 / 177$ & $65.7 / 34.3$ \\
\hline $\begin{array}{l}\text { Age (years) } \\
24-30 / 31-35 / 36-40 / 41-45\end{array}$ & $324 / 180 / 6 / 6$ & $62.8 / 34.9 / 1.2 / 1.2$ \\
\hline Marital status (Single/Married) & $228 / 288$ & $44.2 / 55.8$ \\
\hline Family size $(<5 / 5-8 />8)$ & $279 / 183 / 54$ & $54.1 / 35.5 / 10.5$ \\
\hline No of dependents None/1-3/4-6/>6 & $177 / 207 / 96 / 36$ & $34.3 / 40.1 / 18.6 / 7$ \\
\hline Year of residency $1^{\text {st }} / 2^{\text {nd }} / 3^{\text {rd }} / 4^{\text {th }} / 5^{\text {th }}$ & $84 / 93 / 69 / 171 / 99$ & $16.3 / 18 / 13.4 / 33.1 / 19.2$ \\
\hline Nature of set-up Government/Private/Army & $243 / 96 / 177$ & $47 / 18.6 / 34.3$ \\
\hline $\begin{array}{l}\text { Total no. of residents in the department } \\
<4 / 4-7 / 8-12 / 13-16 / 17-20 / 21-24 / 25-28 />28\end{array}$ & $51 / 102 / 39 / 81 / 60 / 72 / 69 / 42$ & $\begin{array}{c}\text { 9.9/19.8/7.6/15.7/11.6/14/ } \\
13.4 / 8.1\end{array}$ \\
\hline Total no. of supervisors $1 / 2 / 3 / 4 / 5 />5$ & $159 / 84 / 159 / 39 / 21 / 54$ & $30.8 / 16.3 / 30.8 / 7.6 / 4.1 / 10.5$ \\
\hline $\begin{array}{l}\text { No. of International Medical Graduates as residents } \\
\text { None } / 1-3 />3\end{array}$ & $429 / 45 / 42$ & $83.1 / 8.7 / 6.4$ \\
\hline $\begin{array}{l}\text { Monthly take home salary } \\
\text { (Rs) }<30,000 / 30,000-50,000 / 50,000-80,000 />80,000\end{array}$ & $138 / 52 / 156 / 156$ & $26.7 / 10 / 30.2 / 30.2$ \\
\hline Locum (Yes/No) & $192 / 324$ & $37.2 / 62.8$ \\
\hline Strong ties with the city of residency (Yes/No) & $318 / 198$ & $61.6 / 38.4$ \\
\hline $\begin{array}{l}\text { No. of work days per month } \\
15-20 / 21-25 / 26-30\end{array}$ & $45 / 204 / 267$ & $8.7 / 39.5 / 51.7$ \\
\hline $\begin{array}{l}\text { No. of on-calls per month } \\
\text { None/1-3/4-6/7-9/10-13/ } \geq 14\end{array}$ & $66 / 129 / 144 / 90 / 60 / 27$ & $12.8 / 25 / 27.9 / 17.4 / 11.6 / 5.2$ \\
\hline No. of weekend-on-calls per month (0/1-2/3-4) & $114 / 360 / 42$ & $22 / 70 / 8$ \\
\hline $\begin{array}{l}\text { No. of long days per month } \\
\text { None/1-3/4-6/7-9/10-13/ } \geq 14\end{array}$ & $114 / 117 / 105 / 69 / 51 / 60$ & $\begin{array}{c}22.1 / 22.7 / 20.3 / 13.4 / \\
9.9 / 11.6\end{array}$ \\
\hline
\end{tabular}




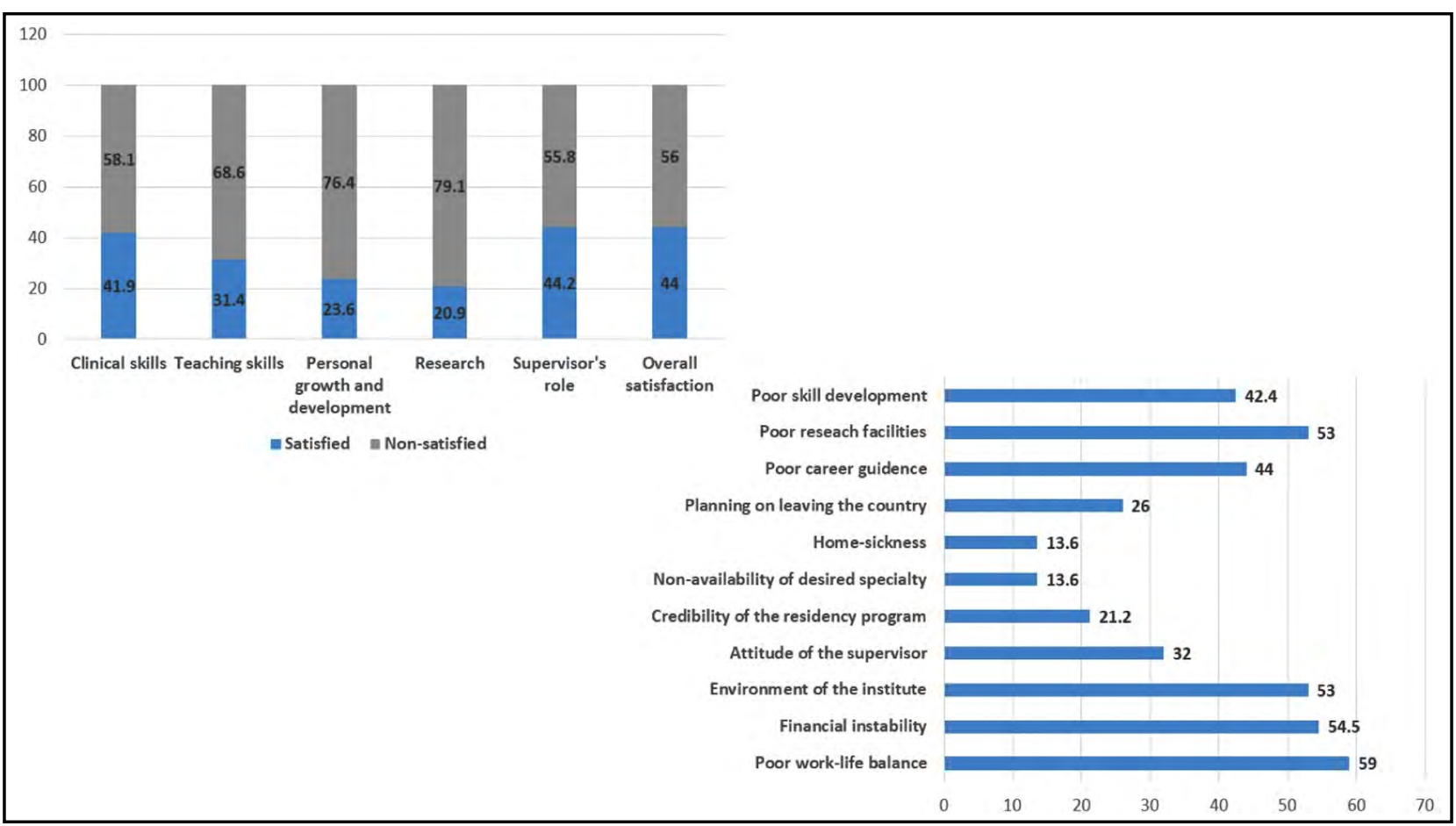

Fig.2: Overall satisfaction of the trainees with reasons for non-satisfaction towards various facets of training.

Senior years of residency, government and private set-ups, less than four and greater than 13 residents on average with less than three supervisors per department, excessive duty hours and financial instability in-lieu of not doing locums were statistically significant in relation to poor satisfaction across majority of the facets of residency as well the overall satisfaction towards training programs (Table-III).

\section{DISCUSSION}

An extensive analysis of our residency programs by Biggs JS in 2008 pointed out several shortcomings including the lack of stipend for full time residents, poor career guidance with poor clinical skills procurement, disregard towards the laidout curriculum, too many trainee doctors with too few mentors to supervise, lack of research and adequate hospital facilities and a serious dearth of evaluation of the residency programs. ${ }^{11}$ Although there is a clear national interest in training of doctors, hardly any improvement has been observed over more than a decade.

Job satisfaction is intrinsically linked to engagement and recognition, financial compensation (in the form of pay scale) and worklife balance, ${ }^{12}$ all of which were unfortunately reported to be infringed in this study. About $27 \%$ of the trainees iterated a monthly salary of less than
Rs. 30,000 (187 USD) and 37\% less than Rs. 50,000 (314 USD) with $89 \%$ of the trainees reporting no financial compensation for extra duty hours. The financial constraints can be easily deduced from the fact that $56 \%$ of the trainees were married and had, on average, three or more dependents with only $37 \%$ managing to supplement their salary with locums.

Poor research skills and non-availability of funding or protected research hours were common for all the residents irrespective of the hospital set-up and is the facet that scored the lowest in terms of satisfaction in this study. Our residency programs need to bring about changes to help equip the trainees with agility to encourage lifelong learning and to foster research culture. ${ }^{13}$

Revalidations for the supervisors and assessment of the training were not available for many of the residency programs in our study. An adequately trained supervisor is integral for an effective clinical program and learner's autonomy and it is the responsibility of the College of Physicians and Surgeons of Pakistan to prepare their faculty for this role. ${ }^{14}$ Despite all the hurdles and resource limitations, the supervisors are doing their best to provide quality training and their role was the only facet in the current study that showed maximum satisfaction in comparison. 
Quality of post-graduate training programs

Table-II: Assessment of the quality of training programs using five-point scale.

\begin{tabular}{|c|c|c|c|c|c|}
\hline As per CPSP recommendation, are you provided with/facilitated in: & $\begin{array}{l}\text { Strongly } \\
\text { agree }\end{array}$ & Agree & Neutral & Disagree & $\begin{array}{l}\text { Strongly } \\
\text { disagree }\end{array}$ \\
\hline \multicolumn{6}{|l|}{ Clinical skills } \\
\hline Hands on & $84(16.3)$ & $123(23.8)$ & $153(29.7)$ & $51(9.9)$ & 105(20.3) \\
\hline Elective rotations & $90(17.4)$ & $81(15.7)$ & $93(18)$ & $69(13.4)$ & $183(35.5)$ \\
\hline Adequate OPD patient exposure & $240(46.5)$ & $105(20.3)$ & $78(15.1)$ & $30(5.8)$ & $63(12.2)$ \\
\hline Adequate OT/procedure room exposure & 105(20.3) & $132(25.6)$ & 99(19.2) & 66(12.8) & $114(22.1)$ \\
\hline Adequate supervision during procedures & $72(14)$ & $120(23.3)$ & $138(26.7)$ & $57(11)$ & $129(25)$ \\
\hline Adequate exposure to advance procedures & $39(7.6)$ & $132(25.6)$ & $138(26.7)$ & $66(12.8)$ & $141(27.3)$ \\
\hline Adequate direct/indirect supervision & $63(12.2)$ & 105(20.3) & $168(32.6)$ & $75(14.5)$ & $105(20.3)$ \\
\hline Mandatory workshop & 102(19.8) & $162(31.4)$ & $111(21.5)$ & $69(13.4)$ & $72(14)$ \\
\hline Adequate range of pathology and patient volume & $69(13.4)$ & 117(22.7) & 177(34.3) & $42(8.1)$ & $111(21.5)$ \\
\hline \multicolumn{6}{|l|}{ Teaching skills } \\
\hline Attending/presenting MDT & $63(12.2)$ & $99(19.2)$ & $99(19.2)$ & $165(32)$ & $90(17.4)$ \\
\hline $\begin{array}{l}\text { Presenting/ attending clinical presentation, morning meetings, } \\
\text { CBDs, CPC etc. }\end{array}$ & $162(31.4)$ & $165(32)$ & $72(14)$ & $84(16.3)$ & $33(6.4)$ \\
\hline Receiving teaching sessions by consultants & $54(10.5)$ & $150(29.1)$ & 102(19.8) & 102(19.8) & $108(20.9)$ \\
\hline Teaching sessions by trainees to juniors & $81(15.7)$ & $183(35.5)$ & $123(23.8)$ & $84(16.3)$ & $45(8.7)$ \\
\hline \multicolumn{6}{|c|}{ Personal growth and development } \\
\hline Recommendations and experience certificates & $69(13.4)$ & $84(16.3)$ & 177(34.3) & $87(16.9)$ & 99(19.2) \\
\hline Attending in-person medical conferences & $45(8.7)$ & $93(18)$ & $144(27.9)$ & $90(17.4)$ & 144(27.9) \\
\hline Evaluations and appraisals & $33(6.4)$ & $75(14.5)$ & 162(31.4) & $132(25.6)$ & $114(22.1)$ \\
\hline Does your institute provide BLS and ACLS accreditation & $69(13.4)$ & $93(18)$ & $105(20.3)$ & $69(13.4)$ & 180(34.9) \\
\hline Acquiring CMEs and maintaining a portfolio & $39(7.6)$ & $75(14.5)$ & $138(26.7)$ & $132(25.6)$ & 132(25.6) \\
\hline Are you able to balance work and personal life & $39(7.6)$ & $87(16.9)$ & $144(27.9)$ & $129(25)$ & $117(22.7)$ \\
\hline $\begin{array}{l}\text { Does your program have the ability to encourage and } \\
\text { support life-long learning? }\end{array}$ & $45(8.7)$ & 105(20.3) & $138(26.7)$ & 102(19.8) & $126(24.4)$ \\
\hline \multicolumn{6}{|l|}{ Research } \\
\hline A dedicated research unit & $24(4.7)$ & $66(12.8)$ & $123(23.8)$ & 96(18.6) & 207(40.1) \\
\hline Planning and execute audits/quality improvement projects & $57(11)$ & $60(11.6)$ & $114(22.1)$ & $120(23.3)$ & $165(32)$ \\
\hline Database, seminars/teaching sessions and help with topic selection & $33(6.4)$ & $51(9.9)$ & $138(26.7)$ & $123(23.8)$ & $171(100)$ \\
\hline Funding from institute & $18(3.5)$ & $30(5.8)$ & $69(13.4)$ & $153(29.7)$ & 246(47.7) \\
\hline Presenting papers/posters & $42(8.1)$ & $117(22.7)$ & $129(25)$ & $96(18.6)$ & 132(25.6) \\
\hline Protected academic or research time per week & $30(5.8)$ & $24(4.7)$ & $132(25.6)$ & $129(25)$ & 201(39) \\
\hline \multicolumn{6}{|l|}{ Supervisor's role } \\
\hline Adequate time spent in weekly clinical activities by the supervisors & $39(7.6)$ & $123(23.8)$ & $111(21.5)$ & 96(18.6) & 147(28.5) \\
\hline Adequate time spent in weekly research activities & $12(2.3)$ & $111(21.5)$ & $108(20.9)$ & $105(20.3)$ & $180(34.9)$ \\
\hline Adequate supervision by the faculty & $45(8.7)$ & 93(18) & $114(22.1)$ & $114(22.1)$ & $150(29.1)$ \\
\hline Adequate clinical skills of the faculty & $117(22.7)$ & $186(36)$ & 105(20.3) & $30(5.8)$ & $78(15.1)$ \\
\hline Revalidation and assessment programs for the supervisors & $30(5.8)$ & $126(24.4)$ & $132(25.6)$ & $48(9.3)$ & $180(34.9)$ \\
\hline $\begin{array}{l}\text { Are your training supervisor and administrative office } \\
\text { well informed of residents' issues? }\end{array}$ & $54(10.5)$ & $123(23.8)$ & $129(25)$ & $90(17.4)$ & $120(23.3)$ \\
\hline $\begin{array}{l}\text { Are your training supervisor and administrative office } \\
\text { responsive to residents' issues? }\end{array}$ & $45(8.7)$ & 108(20.9) & $135(26.2)$ & $81(15.7)$ & 147(28.5) \\
\hline \multicolumn{6}{|l|}{ 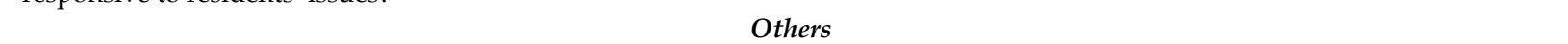 } \\
\hline Does your institute provide Hospital accommodation? & 99(19.2) & $105(20.3)$ & $96(18.6)$ & $60(11.6)$ & $156(30.2)$ \\
\hline Do you have an adequately functioning Cafeteria? & $132(25.6)$ & $111(21.5)$ & $126(24.4)$ & $51(9.9)$ & 96(18.6) \\
\hline Do you have an adequately functioning doctor's room? & $108(20.9)$ & $120(23.3)$ & $120(23.3)$ & 60(11.6) & $108(20.9)$ \\
\hline Do you get paid for extra working hours? & 0 & $30(5.8)$ & $27(5.2)$ & $9(1.7)$ & $450(87.2)$ \\
\hline Do you regularly receive patient feedback? & $27(5.2)$ & $69(13.4)$ & $177(34.3)$ & $87(16.9)$ & $156(30.2)$ \\
\hline Do you regularly receive peer feedback? & $42(8.1)$ & $39(7.6)$ & $177(34.3)$ & $108(20.9)$ & $150(29.1)$ \\
\hline Have you experienced workplace harassment? & $84(16.3)$ & $66(12.8)$ & $75(14.5)$ & 99(19.2) & 192(37.2) \\
\hline Have your peers experienced workplace harassment? & 75(14.5) & $102(19.8$ & $117(22.7)$ & 63(12.2) & 159(30.8) \\
\hline Do you have a workplace harassment monitoring and control disciplinary te & $\mathrm{m} ? 21(4.1)$ & $99(19.2)$ & $111(21.5)$ & $57(11)$ & $228(44.2)$ \\
\hline Is the atmosphere generally relaxed and not condescending? & $39(7.6)$ & $117(22.7)$ & $159(30.8)$ & $51(9.9)$ & $150(29.1)$ \\
\hline Are the residency programs essentially similar throughout the country? & $27(5.2)$ & $57(11)$ & $93(18)$ & $96(18.6)$ & $243(47.1)$ \\
\hline Is there any monitoring/evaluation available for your residency program? & $27(5.2)$ & $63(12.2)$ & $162(31.4)$ & $51(9.9)$ & 213(41.3) \\
\hline
\end{tabular}


Table-III: Relation of demographics with overall satisfaction of the trainees using multinomial regression analysis.

\begin{tabular}{|c|c|c|c|c|c|c|}
\hline Variables & $\begin{array}{l}\text { Clinical } \\
\text { skills }(p)\end{array}$ & $\begin{array}{l}\text { Teaching } \\
\text { skills }(p)\end{array}$ & $\begin{array}{c}\text { Personal growth } \mathcal{E} \\
\text { development }(p)\end{array}$ & $\begin{array}{l}\text { Research } \\
(p)\end{array}$ & $\begin{array}{l}\text { Supervisor's } \\
\text { role }(p)\end{array}$ & $\begin{array}{c}\text { Overall } \\
\text { satisfaction }(p)\end{array}$ \\
\hline Gender & 0.008 & $<0.001$ & 0.05 & 0.09 & 0.08 & 0.07 \\
\hline Year of residency & 0.05 & $<0.001$ & $<0.001$ & $<0.001$ & 0.02 & $<0.001$ \\
\hline Set-up & $<0.001$ & $<0.001$ & $<0.001$ & $<0.001$ & $<0.001$ & $<0.001$ \\
\hline Low monthly salary ${ }^{£}$ & 0.03 & 0.92 & 0.55 & $<0.001$ & 0.05 & 0.64 \\
\hline $\begin{array}{l}\text { No of residents per } \\
\text { department }\end{array}$ & $<0.001$ & $<0.001$ & $<0.001$ & $<0.001$ & $<0.001$ & $<0.001$ \\
\hline $\begin{array}{l}\text { No of supervisors per } \\
\text { department }\end{array}$ & $<0.001$ & 0.012 & $<0.001$ & $<0.001$ & $<0.001$ & $<0.001$ \\
\hline Doing locum & $<0.001$ & $<0.001$ & $<0.001$ & $<0.001$ & 0.01 & $<0.001$ \\
\hline Excessive duty hours* & 0.03 & 0.014 & $<0.001$ & $<0.001$ & 0.03 & $<0.001$ \\
\hline
\end{tabular}

${ }^{£}<50,000 \mathrm{Rs} * \geq 10$ on-calls, $>2$ weekend-calls or $\geq 10$ long days per month.

Moreover, 29-34\% of the trainees reported workplace harassment either involving themselves or a colleague with only $23 \%$ of the institutions providing disciplinary committees to deal with these allegations. A study by $\mathrm{Hu} \mathrm{Y}$ et al demonstrated that $59.4 \%$ of medical trainees had experienced at least one form of harassment or discrimination during their training with consultants being the most common perpretrator. ${ }^{15}$ The authors believe the percentage of work-place harassment might be under-reported due to the stigma attached to disclosure and, more importantly, many of our trainees usually don't know what constitutes workplace harassment and bullying. ${ }^{16}$ There is a need for stringent policies and cultural change at our set-ups to provide a healthy progressive environment.

There was a common trend seen regarding nonsatisfaction across all the facets of training that included working in public set-ups, greater number of residents per department versus lower number of supervisors for mentoring, excessive duty hours and financial instability in relation to not doing locums. The trainees working in army set-ups showed higher levels of satisfaction and reported better clinical skills with greater contentment towards supervisors' role in their residency programs. On the contrary, $>5$ supervisors in a department were considered to be adversely affecting the clinical skills, likely because of less opportunity provided for hands-on and advanced skill procurement. Junior trainees were not happy with their supervisors whereas senior trainees showed a relatively higher non-satisfaction towards their clinical and teaching skills development, findings similar to a study conducted on Greek residents. ${ }^{17}$
Female trainees conveyed a statistically significant non-satisfaction towards their clinical and teaching skills which has been studied extensively in the past showing gender based discrimination in residency and practice. ${ }^{18}$ Male residents were not happy with their personal growth and development and the over-all nonsatisfaction was related to $<4$ or $>13$ residents per department with $<3$ supervisors, higher residency year (likely secondary to the realization that the program failed a trainee's initial expectations) $)^{17}$ and financial constraints through multinomial regression analysis.

It was interesting to see that for some of the survey questions the neutral response was as high as $34.3 \%$, a trend observed in a similar local study. ${ }^{5}$ It has been seen that choosing a neutral option provides an easy out for the participants who are less willing to express their opinion or when they are reluctant to voice a socially disagreeable sentiment. ${ }^{19}$ This aloofness might be one of the biggest confounders responsible for the lack of prompting for conceivable policies and an imperative change.

Resident doctors' burnout in lieu of poor organizational systems is one of the most notorious factors for eroding their wellness and affecting the patients' quality of care and general satisfaction. ${ }^{20}$ Reflection, leadership, continuous monitoring and assessment with residents' feedback are paramount for a cohesive and robust curriculum that has the ability to encourage and support life-long learning.

Limitations of the Study: The only limitation of the study is simple convenience sampling. 


\section{CONCLUSION}

There is a tremendous scope for improvement in the recognized and partially acknowledged attributes of our training programs. Regular monitoring of the training programs along with repeated validation of the supervising mentors is mandatory for improved outcomes. Yearly feedback surveys involving residents is essential for enlightening the authorities and mitigating the trainees' grievances.

\section{REFERENCES}

1. dos Santos R, Snell L, Tenorio NM. The link between quality and accreditation of residency programs: the surveyors' perceptions. Med Educ Online. 2017;22(1):1270093. doi: 10.1080/10872981.2016.1270093

2. Fishbain D, Danon YL, Nissanholz-Gannot R. Accreditation systems for Postgraduate Medical Education: a comparison of five countries. Adv Health Sci Educ. 2019;24:503-524. doi: 10.1007/s10459-019-09880-x

3. Saaiq M, Khaleeq-Uz-Zaman. Residents' perceptions of their working conditions during residency training at PIMS. J Coll Physicians Surg Pak. 2010;20(6):400-404.

4. Tariq M, Syed NA, Motiwala A, Jafri W, Hameed K, Islam $\mathrm{N}$, et al. Effectiveness of educational interventions in improving clinical competence of residents in an internal medicine residency program in Pakistan. Educ Health. 2011;24(3):573.

5. Saaiq $M$, Khaleeq-uz-Zaman. Postgraduate medical education: residents rating the quality of their training. J Coll Physicians Surg Pak. 2013;23(1):72-76.

6. Rathore F, Butt A, Soomro N, Akhtar N. A QuestionnaireBased Survey of Physical Medicine and Rehabilitation Residency Training in Pakistan. Cureus. 2017;9(1):e1005. doi: 10.7759 /cureus.1005

7. Khan AA, Shaikh S, Ahmad Z, Zafar M, Anjum MU, Tahir A, et al. Quality of post graduate medical training in public and private tertiary care hospitals of Karachi. J Postgrad Med Inst. 2014; 28(1):13-18.

8. General Medical Council. Quality assurance (QA) programme review. Internal research report - May 2018. Available At: https://www.gmc-uk.org/-/ media/gmc-site-images/about/quality-assuranceprogramme-review---internal-report.pdf?la=en\&hash= 654842DED0ECF69591832EA5001F99915553BFE9 [cited 8 February 2021]

9. Alam L, Alam M, Kazmi SKH, Kazmi SAH. Impact of COVID-19 pandemic on the residency programs of the country: A multicentre study. Pak J Med Sci. 2021;37(2):367-372. doi: 10.12669/pjms.37.2.3496

10. Alam L, Kazmi SK, Alam M, Faraid V. Amid COVID-19 pandemic, are non-COVID patients left in the lurch? Pak J Med Sci. 2021;37(2):576-581. doi: 10.12669/pjms.37.2.3536
11. Biggs JS. Postgraduate medical training in Pakistan: observations and recommendations. J Coll Physicians Surg Pak. 2008;18(1):58-63.

12. Ofei-Dodoo S, Scripter C, Kellerman R, Haynes C, Marquise ME, Bachman CS. Burnout and job satisfaction among family medicine residency coordinators: results from a national survey. Fam Med. 2018;50(9):679-684. doi: 10.22454/FamMed.2018.921094

13. Basavareddy A, Pallamparthy S. Knowledge, attitude, practice, and barriers toward research among medical students: A cross-sectional questionnaire-based survey. Perspect Clin Res. 2019;10(2):73. doi: 10.4103/picr. PICR_1_18

14. Whalen T, Wendel G. New Supervision Standards: Discussion and Justification. [Internet]. Acgme.org. 2021 [cited 10 February 2021]. Available from: https://www. acgme.org/Portals/0/PDFs/jgme-11-00-39-45[1].pdf

15. Hu Y, Ellis R, Hewitt D, Yang A, Cheung E, Moskowitz $\mathrm{J}$, et al. Discrimination, Abuse, Harassment, and Burnout in Surgical Residency Training. N Engl J Med. 2019;381(18):1741-1752. doi: 10.1056/NEJMsa1903759

16. Miller B. Why Does Workplace Harassment Go Unreported? - HR Daily Advisor [Internet]. HR Daily Advisor. 2021 [cited 10 February 2021]. Available from: https:/ /hrdailyadvisor.blr.com/2019/08/20/why-doesworkplace-harassment-go-unreported/

17. Gkolfakis P. A nationwide survey of training satisfaction and employment prospects among Greek gastroenterology fellows. Ann Gastroenterol. 2017;30(2):242-249. doi: 10.20524/aog.2016.0111

18. Bruce A, Battista A, Plankey M, Johnson L, Marshall M. Perceptions of gender-based discrimination during surgical training and practice. Med Educ Online. 2015;20(1):25923. doi: 10.3402/meo.v20.25923

19. Edwards ML, Smith BC. The Effects of the Neutral Response Option on the Extremeness of Participant Responses. Incite. 2021 [cited 10 February 2021]. Available from: https://blogs.longwood.edu/incite/2014/05/07/ the-effects-of-the-neutral-response-option-on-theextremeness-of-participant-responses/

20. Talen M, Edberg D, Pence A, Khan L. Monitoring the organizational wellness of a physician residency program: A quality improvement process. Int J Psychiatr Med. 2019;54(4-5):316-326. doi: 10.1177/0091217419862480

\section{Author Contribution:}

LA, JK, MA: Contributed to the idea, questionnaire and data collection.

LA: Contributed to the design, statistical analysis and drafting of the manuscript.

VF, FA, LB: Contributed to data collection.

All authors take equal responsibility for the accuracy and integrity of the work. 